\title{
Changes in Approach to Customer Loyalty
}

\author{
Katarzyna Szczepańska', Patryk Paweł Gawron²
}

\begin{abstract}
The article discusses an overview of customer loyalty theoretical framework. It presents both, the classic approach to the subject of loyalty as well as the results of its ongoing evolution. This allowed the identification of factors affecting customer loyalty and a statement that the concept of loyalty can be seen in varying degrees, in terms of criteria other than behavioral. Finding of not enough empirical research on customer loyalty in the long types of market and specific customer groups indicates a cognitive gap. Verification of the classic determinants of customer loyalty authorized to conclude that the profitability of the customer portfolio sets new definition of loyalty, which is related to the concepts of marketing value and value based management. This is supported by associations of loyalty to the management parameters.
\end{abstract}

Key words: customer and business loyalty, marketing value, customer portfolio

\section{JEL Classification: L19, L53, M31}

${ }^{1}$ Warsaw University of Technology, Poland

${ }^{2}$ Warsaw University of Technology, Poland

\section{Introduction}

Presented in the literature, the concept of diversification of customer loyalty and its importance for the company due to the development of the concept of market services. One can assume that the relationship began marketing the changes in the approach to customer loyalty. However, the crucial breakthrough came with the increase in the use of value based marketing in the practice of business. It is widely recognized that reflects the effectiveness of customer loyalty in marketing activities, which indicates the nature of the output. Customer loyalty can also be understood as a factor in determining long-term growth and margin business, so has a functional dimension. If the customer loyalty will be subjected to valuation, it can be considered as part of the company's capital (dimension value). This explains the reasons for differences of terminology used in describing the concept of customer loyalty, as well as the perspective of customer loyalty management. Based on research, the following

Corespondence concerning to this article should be addressed to: katarzynasz@autograf.pl article examines ongoing changes in the definition and classification of customer loyalty.

\section{Terminological perspective of cus- tomer loyalty}

From praxeological viewpoint, customer loyalty can be defined as a constant and positive attitude towards an object (i.e. brand or business enterprise). Marketing definition of loyalty traditionally covered two aspects of the phenomenon: behavioural aspect and attitudinal aspect. Behavioural loyalty explained customers' actions, which included repeat purchases, their proneness to be attracted by competitors' marketing efforts as well as their willingness to engage in word-of-mouth marketing.

Without a doubt, the classic approach to customer loyalty ignored factors affecting the attitudes and behaviour and does not include themes of loyalty. Taking into account categories such as income or lack of alternatives to choose from, we can say that the nature of economic factors determine the customer loyalty. If, however, will be included in the analysis of the determinants of market, demographic, or cultural, it reveals a broad context 
for consideration of the factors influencing and shaping the loyalty of company's customers.

„Loyalty in the behavioural sense is measured using repurchase probability, long-term choice probability, or switching behaviour. In the attitudinal sense, loyalty is operationalized as brand preference or emotional commitment and is, therefore, measured with repurchase intention, resistance against better alternatives, price tolerance, and intention to recommend the product or service" (Brunner at al., 2010:1096).

Based on presented discussion, one must question the validity of loyalty whenever displayed loyal behaviour (i.e. repeat purchase) stems from barriers imposed by the goods provider, such as any limitations included in business contract. Customers' passive attitude caused by objective (e.g. transaction characteristics) as well as subjective (e.g. customer's indifference) factors teamed up with their repeat purchases inevitably leads to a conclusion that such scenario may not be perceived as one exemplifying loyalty. So, it seems clear that in order to discuss loyalty we must take into account a certain degree of emotional engagement displayed by a customer. On the one hand, such statement highlights the need to examine the levels of emotional engagement displayed by customers. On the other hand, voiced need to examine customers' emotional engagement widens the scope of any discussion on loyalty as well as any marketing activity designed and implemented by a business enterprise. Any discussion on loyalty cannot fail to include careful examination of customer satisfaction levels, which are shaped by customer's subjective evaluation of purchased product/ service, received value, and overall interaction with a company (see: Figure 1).

Figure 1. Conceptual model of loyalty

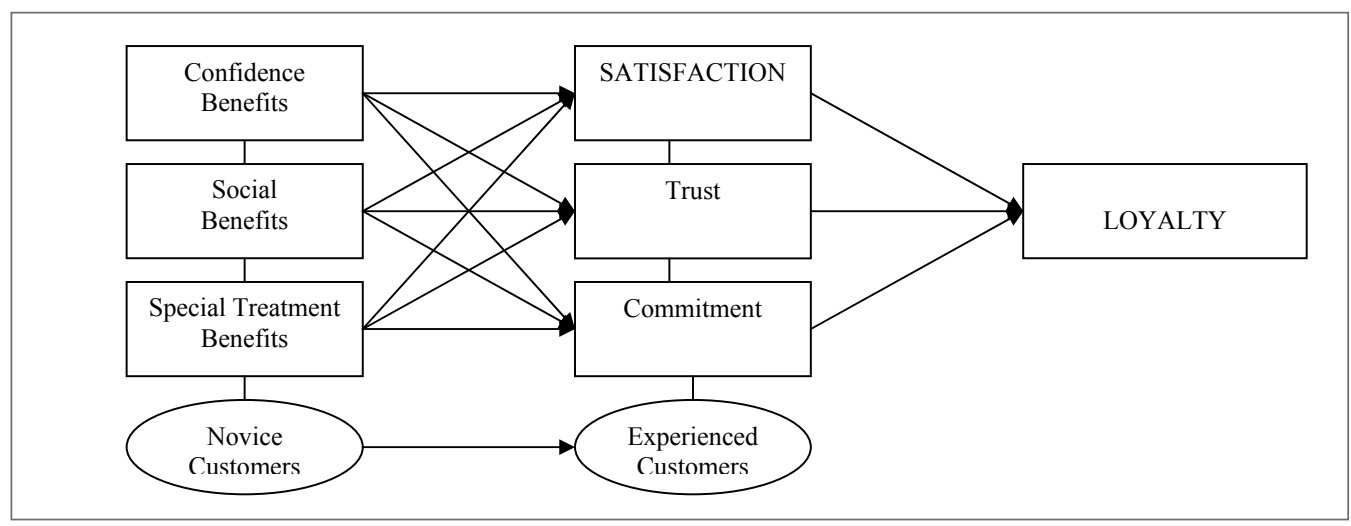

Source: based on: Dogger, at al., 2010:1534.

Figure 2. Factors of customer loyalty

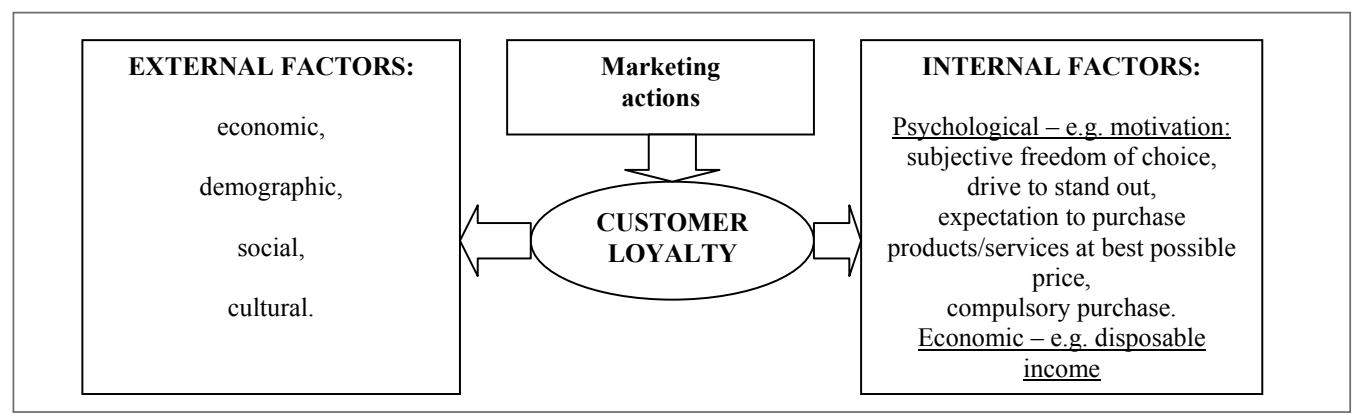


„Confidence benefits refer to perceptions of reduced anxiety and comfort in knowing what to expect in the service encounter; social benefits are the emotional part of the relationship (...), special treatment benefits pertain to price breaks, faster service or individual service for those customers with an established relationship (...). Satisfaction, trust and commitment depending on the customers' level of relationship experience. Understanding these effects is critical if firms are to enhance satisfaction, trust and commitment and ultimately build a loyal customer base"(Dogger, at al., 2010:1534). The structure of the generic factors that shape customer loyalty presented in Figure 2.
Wide variety of factors affecting customer loyalty makes it nearly impossible to present a straightforward and complete definition of the discussed term. Generally brand loyalty is defined as "a deeply held commitment to rebuy or repatronize a preferred product/service consistently in the future, thereby causing repetitive same-brand or same brand-set purchasing, despite situational influences and marketing efforts having the potential to cause switching behavior" (Ha, at al., 2011:676). Any inconsistencies in the meaning of loyalty should be clarified by the overview of accepted definitions of the term presented in the following table (see: Table 1).

Table 1. Overview of customer loyalty definitions

\begin{tabular}{|c|c|}
\hline Author & Definition \\
\hline The Global Loyalty Agency & $\begin{array}{l}\text { all the feelings or experiences that would incline a customer to consider the re- } \\
\text { purchase of a particular product, service or brand or re-visit particular company, shop } \\
\text { or website }\end{array}$ \\
\hline Newnan J.W., Werbel R.A. & $\begin{array}{l}\text { repeat purchase of a particular brand, without considering purchase of any other } \\
\text { available brand }\end{array}$ \\
\hline Jacoby J., Chestnut R.W., Day G.S. & customer's predisposition towards the brand as a function of psychological processes \\
\hline Storbacka K., Lehtinen J.R. & intention to act and willingness to interact with others \\
\hline Bloemer J., de Ruyter K. & $\begin{array}{l}\text { customers' non-incidental and intentional actions displayed over a long period of time } \\
\text { towards a particular service/product supplier which operates among numerous and } \\
\text { similar service/product suppliers }\end{array}$ \\
\hline Olivier R.L. & $\begin{array}{l}\text { deeply-term engagement and product/service/brand re-purchase intention displayed } \\
\text { toward a particular product, service or brand }\end{array}$ \\
\hline Reichheld F.F. & willingness to invest in further product/service/brand relationship development \\
\hline Dick A.S., Basu K. & function of attitude manifested in behaviour \\
\hline Jacoby J., Kyner B.D & $\begin{array}{l}\text { the biased (i.e. non-random), behavioural response (i.e. purchase), expressed over time, } \\
\text { by some decision making unit, with respect to one or more alternative brands out of a } \\
\text { set of such brands, and is a function of psychological (i.e. decision making, evaluation) } \\
\text { processes }\end{array}$ \\
\hline Zawadzka A.M. & $\begin{array}{l}\text { the result of rational-functional motivation teamed up with emotional-symbolic } \\
\text { motivation }\end{array}$ \\
\hline
\end{tabular}

Source: own study based on: Urban at al., 2008:11-14; http://www.iclployalty.com (accessed on 18/10/2010); Bloemer at al., 1998 : 499-513; McMullan at al., :2010:1085. 
As shown in the loyalty definitions overview, most academic discussions on the topic take into account behavioural and psychological loyalty drivers. As a result, for a considerable period of time loyalty was predominately perceived as a regular re-patronage or re-purchase driven by intentional, premeditated customer's actions and accompanied by positive attitude. Consequently, most presented loyalty definitions were drawn on the assumption that two main sets of loyalty drivers (i.e. behavioural and psychological driv- ers) should be analysed separately and independently, without the need to examine any correlations existing between discussed drivers. Nevertheless, it is evident that such correlations should be taken into account and closely examined, which may help with critical classification of existing loyalty definitions (see: Table 2). The examination of those correlations allows for identification of new loyalty drivers (i.e.: action-based, follow-up) which always remain closely linked and intertwined.

Table 2. Loyalty drivers and definitions

\begin{tabular}{|c|c|}
\hline Driver & Definition \\
\hline \multirow{4}{*}{ Psychological } & high level of emotional attachment to company's employees, products or services \\
\hline & combined role of psychological processes \\
\hline & intention to act and willingness to engage with others \\
\hline & strong drive to re-purchase specific brand or specific set of brands despite unfavourable circumstances \\
\hline Action-based & $\begin{array}{l}\text { systematic, intentional repurchase of a specific product/service/brand accompanied by strong convic- } \\
\text { tion that selected product/service/brand is superior to other available options }\end{array}$ \\
\hline Follow-up & $\begin{array}{l}\text { the result of customers' learning process, which confirms that selected product/service/brand fulfils their } \\
\text { needs and meets their expectations to a far greater extent than any other available product/service/ } \\
\text { brand (brings a unique and desired benefits) }\end{array}$ \\
\hline
\end{tabular}

Source: own study based on Garbarski at al., 2001: 347-348; Urban at al., 2008: 12; Rudawska, 2005: 27; Dębski, $2009: 40$.

It should be noted that the classifications omit reference to specific markets (B2B, B2G). Moreover, in varying degrees, refer to the types of objects that are the subject of loyalty (product category, personnel, place of purchase, brand, and organization).

Most available literature on the discussed subject matter tends to focus on brand loyalty in B2C markets. As demonstrated in extensive research studies (Falkowski at al., 2009: 307):

- there is correlation between the levels of perceived satisfaction and brand loyalty (only satisfied customers declared brand loyalty);
- brand loyal customers do not always declare complete contentment with their purchase;

- satisfied customers generally declare a certain level of brand loyalty.

Those findings seem to justify why customer loyalty is often categorized based on customers' brand awareness (where brand awareness is perceived as one of key loyalty drivers). Moreover, the supremacy of brand awareness in loyalty classification enables clear and comprehensive distinction of two main sources of customer loyalty (see: Table 3). 
Table 3. Types of loyalty

\begin{tabular}{|c|c|}
\hline Source of loyalty & Type of loyalty \\
\hline \multirow{3}{*}{ brand awareness } & $\begin{array}{l}\text { real - preferred brand is perceived as best available and fulfils all customer's expectations. } \\
\text { Loyalty is based on significant brand preference supported by high levels of repurchase. }\end{array}$ \\
\hline & $\begin{array}{l}\text { common - brand preference is largely based on regular custom, a customer does not per- } \\
\text { ceive the brand as superior. Loyalty is at the background of habits in the process of purchase. }\end{array}$ \\
\hline & $\begin{array}{l}\text { forced - brand preference is largely based on unfavourable circumstances. Repeat buying } \\
\text { stems from a significant lack of reasonable alternatives or is a direct result of low levels of dis- } \\
\text { posable income (i.e. other available options are too expensive). Loyalty shaped by excitation } \\
\text { by external factors. }\end{array}$ \\
\hline \multirow{4}{*}{$\begin{array}{l}\text { product/service provider } \\
\text { attachment }\end{array}$} & lack of loyalty - customers with low level of relative attachment and low repeat purchase; \\
\hline & $\begin{array}{l}\text { hidden loyalty - customers with high level of relative attachment coupled with low repeat } \\
\text { purchase; }\end{array}$ \\
\hline & true loyalty - customers with high level of attachment and regular repeat patronage; \\
\hline & $\begin{array}{l}\text { false loyalty - may stem from regular custom; customers with high repeat purchase and low } \\
\text { (negative) attachment. }\end{array}$ \\
\hline
\end{tabular}

Source: own study based on: Kaczmarczyk, 2007: 110; Urban at al., 2008: 82.

Presented discussion confirms high levels of complexity and ambiguity of customer loyalty. It seems that this very complexity makes it extremely difficult to draw a straightforward and comprehensive definition of the discussed term. The multitude of existing definitions of customer loyalty can be explained by growing heterogeneity of various markets as well as increasing range of internal and external factors affecting both, buyers and suppliers. Market characteristics (subjective, objective) and its broad determinants justify both the multiplicity and extent of use of the concept of customer loyalty.

\section{The impact of Value Based Market- ing on customer loyalty}

„Several researchers analyze value creation from the so-called functionalist perspective. The basic underlying premise in this approach is that companies can carry out a series of functions that create value for their commercial partners. By means of these functions, companies can help their counterparts in "the accumulation of knowledge, the creation of new resources and the development of new activities" (Sanchez at al.,
2010:1616). The emerging need to draw a set of new targets for marketing management in business enterprises was triggered by a host of external factors (e.g.: increasing globalization of business operations, emergence of services as one of the driving factors in today's economy, observed information revolution, evolving customers' expectations, etc.) as well as the advent of Value Based Marketing (VBM) philosophy. Therefore, in order to create a tangible value for the shareholders acting in modern markets, the marketing managers must strive to increase the overall long-term company's net worth. For this very reason it is often assumed that the efficiency of company's marketing efforts is reflected by high levels of its discounted cash flow. In order to achieve such goal, all marketing activities undertaken by a company must be aimed at increasing net value of its customers and focus on all marketingrelated factors that affect overall value: selecting most profitable target markets, correct segmentation of selected target markets, devising strategic competitive advantage which differentiates the company from its closest competitors, and selecting the most appropriate marketing-mix. Moreover, any marketing plan 
aimed at creating value for individual customers must be devised in accordance with the following principles (Szczepańska, 2010:274):

- customers choose only those suppliers, who offer the highest levels of perceived value;

- customers are driven mainly by subjectively perceived probability that selected product/service/ brand will fulfil their needs (e.g. economic needs, emotional needs, etc.);

- building long-term relationships with customers triggers their trust and loyalty.

In contemporary markets, commonly accepted measures of customer loyalty (RFM analysis, HHI index) which allow for detailed study of its current levels may be deemed secondary. The most applicable current measure of loyalty is the Customer Lifetime Value $(\mathrm{CLV})$, i.e. the present value of the future cash flows attributed to the customer relationship. Customer Lifetime Value represents exactly how much each customer is worth in monetary terms at any given time and therefore Value Based Marketing often assumes that customer profitability (not customer attitudes and/or behaviour) is the main measure of loyalty. Such assumption does not exclude attitudes and behaviour as factors affecting loyalty, yet their importance in loyalty building is limited to:

- enforcing loyal behaviour exclusively among profitable customers,

- enforcing loyal attitudes among profitable customers through their ongoing engagement in company's operations.

The importance of discussed notion of customer loyalty in operational marketing is strongly supported by available research data, which suggests that "customer loyalty is the key priority in everyday business operations and is perceived as much more important than ongoing product development, cost reduction and managerial staff development" (Dell, 2002: 8).

\section{Factors affecting the value of loyal customers}

The results of well-established research studies clearly demonstrate that "retention of relatively small numbers of customers boosts profits and results in increased net worth of a company (according to some studies reducing defections by 5 percent boosts profits by 25 percent to 85 percent" (http://www.bain.com: accessed on 18/10/2010)). Based on those findings it can be assumed that loyalty boosts profitability due to: decreased customer acquisition costs, increased base profit, increased turnover, decreased operation costs, increased pricing, and positive word-of-mouth marketing (Doyle, 2003: 96-97). The idea of increased profitability, which stems from cultivating customer loyalty is further supported by the following findings (Reichheld, 1990: 105-111):

- the cost of acquiring a new customer is significantly higher than the cost of retaining a customer (moreover, a newly acquired customer may remain indifferent to company's marketing efforts and relatively quickly choose a competing supplier);

- long-term, satisfied customers purchase more goods/services and therefore boost company's profits;

- as the company gains experience with its customers, it can serve them more efficiently; as the customers gain experience with the company they can buy their favourite products/services more efficiently - therefore, operating costs to serve loyal customers tend decline over time. Moreover, the company and its customers engaged in a long-term relationship tend to develop mutual trust, which allows for better communication, enhanced information exchange and enables the supplier to develop good/services which are in line with customers' needs and expectations;

- loyal customers help grow a business through positive word of mouth (which supports new customers acquisition and may reduce expenditure necessary to provide anonymous public with information on new products/services);

- loyal customer are less price sensitive and therefore less prone to buy low-priced products/services provided by competitors.

The need for verification of the claims, including the concept of marketing value, is confirmed by the results of the study the relationship between loyal customers (loyalty in the behaviour) and the profitability of enterprises. They showed the presence, in most cases, a weak correlation between these variables. Should adopt the general assumption that customers can characterize the different profitability, hence it is necessary to carry out the division into groups (customer segmentation), resulting in the yield can be determined (CLV) called 
customer portfolio. It is seen as a "selection of clients, which ensures the supply of all the streams that generate or may generate for the company in the long term" (Dobiegała-Korona, 2009: 37).

The expenditure necessary for customer retention is commonly referred to as transaction cost, yet it does not always include all the costs stemming from ongoing communication between a company and a customer. The sum of communication costs is often quite high, especially when dealing with an important customer who has been loyal for a long period of time and/or has been placing significant orders. Such customers tend to expect special treatment and unusually high discounts, which makes them extremely expensive to serve. Therefore, it can be concluded that the cost of retaining a customer in today's market may often be much higher than the cost of acquiring a new customer.

The available research (Reinartz at al., 2000:17-35; 2002:86-94) suggests, that loyal customers increase their expenditure with a supplier for a limited period of time (usually several months), after which the quantity purchased tends to stabilize and remain constant. This trend was most evident among so-called gold customers (usually 15-20 percent of all company's customers, characterized by relatively low service costs and generating the largest share of profits). The high profitability of those customers was mainly due to their regular purchases which remained similar in volume, and not by their tendency to increase the volume of the purchases over time. The same research also suggested that companies operating in selected sectors should focus their investments on customers who remain loyal for a fixed period of time, and forsake large investments in customers willing to engage in a longterm relationship. Discussed research findings clearly demonstrate that not all loyal customers are willing to purchase more of their favourite products and increase their spending with a company.

Claiming that the deepening relationship between the customer and the enterprise results in better communication, leading to a reduction in costs associated with customer service, in light of the results proved to be untrue. Latest studies suggest that "average of operating costs of customer service remain constant regardless the length of customer relationship with a company. For some industries, loyal customers are con- sistently more expensive to manage than short-term customers" (Kumar, 2008:18). It is also worth mentioning that "failure to present a loyal customer with a host of incentives that make a potential re-purchase more attractive poses a significant threat to longevity of a relationship. In that case the customer is prone to search for more attractive offers among the company's closest competitors" (Zikmund, at al., 2003:76).

A strong belief that loyal customers help grow a business through positive word of mouth has also lost much of its validity in the recent years. "If we presume that loyalty is reflected in the tenure of customers with a firm, then the relationship between the length of relationship and word of mouth is very weak. If we define loyalty as being attitudinally as well as behaviourally loyal, then customer's propensity to engage actively in word of mouth is higher, yet still not certain" (Keiningham at al., 2005:98). In addition, the characteristics and attributes of the product makes a champion can play both a loyal customer, and incidentally. It is worth noting that the number and frequency of positive opinions propounded by clients depends to a greater extent on the level of satisfaction felt after a single transaction by the customer rather than the sustainability of its relationship with the company.

Justification for the claim that loyal customers are less price-sensitive than non-loyal customers (and therefore less prone to search for more competitive offers) stems from an assumption that "customers will often pay a premium to continue to do business with you rather than switch to a competitor with whom they are neither familiar nor comfortable" (Finnie, at al., 2002:25-31). This claim can be questioned, because rarely loyal customer decides to continue the relationship with the company being forced to incur additional costs. At the same time it is more sensitive to the price level of products, because it is more market - oriented offerings, and above all to a greater extent can assess the quality and value.

\section{Customer loyalty and business management}

Customer loyalty factors and drivers are a basic for loyalty modelling, which can be used for customer behaviour forecasting as well as forecasting of customer preferences observed in future purchase patterns. The accuracy and validity of prepared loyalty models is ulti- 
mately tested by comparing actual customer churn and re-patronage ratio with expected customer behaviour described by the model. Without further examination of loyalty models and modelling techniques it can be concluded that such models are applied in marketing practice and their correct application may lead to increased customer portfolio profitability. Consequently, correct application of loyalty modelling requires testing forecasted hypothesis with properly devised valuation tool, which allows for full parameterisation of marketing actions that increase profitability. Moreover, regular usage of such valuation tools enables marketers to select and focus on potentially most profitable segments. Therefore, regular application of value analysis in marketing management (including valuation of segment profitability) may lead to strengthened relationships with loyal customers.

The ability to devise a correct set of loyalty valuation criteria and to determine potential loyalty within selected customer segments is largely dependent on information resources of individual enterprises as well as the size of their market and the range of products offered. As demonstrated above, the most common causes of low-value ratio loyalty of customers are related to the following factors (Dobiegała - Korona, 2009:18):

- managers' lack of understanding that (...) the levels of customer loyalty and cash flow that stems from loyalty have a direct impact on profitability;

- managers tend to focus on current issues and short-term tactics and are prone to neglect business' long-term vision;

- inability to identify company's customers (customer segments);

- difficulties with determining sets of product values that are important to customers;

- inability to determine the reasons for customer churn;

- insufficient number of professionals with experience in the field of customer loyalty building;

- ineffective communication between the customers and the company.

Listed issues describe a company's potential to develop loyalty in three following categories: managerial (managerial personnel), business systems (information resources, communication), and knowledge (ability to describe target audiences).
The basis of the theoretical concepts of customer value is to assume the existence of client capital. Therefore we can say that customers are financial assets of the company, which should be actively managed. "Dynamic and integrated marketing system that utilizes various techniques of financial assessment (...) in order to optimise, acquire, retain (...) and maximise the value of (...) customers in their lifetime with a company" (Blattberg at al., 2004:25) is called customer capital management. That is why any discussion on customer value should include two basic concepts: the concept of economic value to the customer and the concept of customer equity.

The examination of customer loyalty must also include the significant role it plays in increasing the overall value of companies, which can be exemplified by the following benefits recorded in loyalty-driven businesses (cf. Dobiegała-Korona, 2006: 223):

- stabilization of business operating conditions,

- increased revenue,

- increased market share,

- profit reinvestment

- increased long-term value.

Customer loyalty (previously associated with the field of marketing studies) is becoming a link between management and marketing, and enters the strategic for finance management. In turn, the quantifiable loyalty factors (i.e. customer portfolio profitability) determine the ways in which desired values are devised and presented to the customers. Thus, it can be concluded that customer profitability can be adopted as benchmark for organizing all marketing activities undertaken by a business.

\section{Conclusions}

Presented deliberations clearly demonstrate that customer loyalty is a concept of dynamic nature and thus must be applied in the practice of marketing decisionmaking in line with its changing definition. Current understanding and implications of such loyalty are much broader than previously assumed. The need for extensive examination of loyalty concept stems from its direct relationship with value creation. Previously accepted classification of existing customers (i.e. groups of potential, passive, engaged, regular, and loyal customers) was based on behavioural aspects of purchase patterns and currently can be deemed insuf- 
ficient. Nowadays, loyalty classification exercise must include customer profitability aspect, which allows for detailed and useful segmentation of customer portfolio. Observed shift in customer classification clearly demonstrates that all marketing activities are closely linked with economic and financial aspects of business management. Therefore, the modern concept of loyalty transcends the field of operational marketing and enters the arena of strategic management.

\section{References}

1. Blattberg R.C., Gett G., Thomas J.S., Klient jako kapitał. Budowanie cennego majątku relacji $\mathrm{z}$ klientem i zarządzanie nim, MT Biznes, Warszawa 2004.

2. Bloemer J., de Ruyter K., On the Relationship of Store Image, Store Satisfactions and Store Loyalty, European Journal of Marketing, Vol 32, No 5/6 (1998).

3. Brunner T.A, Stocklin M., Opwis K., Satisfaction, image and loyalty: new versus experienced customers, European Journal of Marketing, Vol 42, No 9/10 (2008).

4. Dell D., The CEO Challenge: Top Marketplace and Management Issues 2002, The Conference Board, New York, 2002.

5. Dębski M., Kreowanie silnej marki, PWE, Warszawa 2009.

6. Dobiegała-Korona B., Wartość dla klientów generatorem wartości przedsiębiorstwa, [in:] DobiegałaKorona B., Herman A. (ed.), Współczesne źródła wartości przedsiębiorstwa, Difin, Warszawa 2006.

7. Dobiegała-Korona B., Migracja klientów a migracja wartości przedsiębiorstwa: szanse i zagrożenia, [in:] Dobiegała-Korona B. (ed.), Migracje klientów a wartość przedsiębiorstwa, Wydawnictwo Naukowe PWN, Warszawa 2009.

8. Dobiegała-Korona B., Istota i pomiar wartości klienta, [in:] Dobiegała-Korona B., Doligalski T., (ed.), Zarządzanie wartością klienta. Pomiar i strategie, Poltext, Warszawa 2009.

9. Dogger T.S., O’Brien T.K., Does experience matter? Differences in relationship benefits, satisfaction, trust, commitment and loyalty for novice and experienced service users, European Journal of Marketing, Vol 44, No 9/10 (2010).
10. Doyle P., Marketing wartości, Felberg SJA, Warszawa 2003.

11. Falkowski A., Tyszka T., Psychologia zachowań konsumenckich, GWP, Gdańsk 2009.

12. Finnie W., Randall R.M., Loyalty as Philosophy and Strategy: An Interview with Frederick F. Reichheld, Strategy \& Leadership Vol. 30, no. 2 (2002).

13. Garbarski L., Rutkowski I., Wrzosek W., Marketing. Punkt zwrotny nowoczesnej firmy, PWE, Warszawa 2001.

14. Ha H., John J., Janda S., Muthaly S., The effects of advertising spending on brand loyalty in services, European Journal of Marketing, Vol 45, No 4 (2011).

15. Kaczmarczyk S., Zastosowania badań marketingowych. Zarządzanie marketingowe i otoczenie przedsiębiorstwa, PWE Warszawa 2007.

16. Keiningham T. L., Vavra T. G., Askoy L, Wallard H., Loyalty myths, John Wiley \& Sons, Inc, New Jersey 2005.

17. Kumar V., Managing Customers for Profit: Strategies to Increase Profits and Build Loyalty, Wharton School Publishing, New Jersey 2008.

18. McMullan R., Gilmore A., Customer loyalty: an empirical study, European Journal of Marketing, Vol 42, No 9/10 (2010).

19. Reichheld F., Sasser W., Zero defects: quality comes to services, Harvard Business Review, Vol. 68 Issue 5 (1990).

20. Reinartz W., Kumar V., On the Profitability of Long - Life Customers in a Noncontractual Setting: An Empirical Investigation and Implications for Marketing, Journal of Marketing, No. 4 (2000).

21. Reinartz W., Kumar V., The Mismanagement of Customer Loyalty, Harvard Business Review, No. 7 (2002)

22. Rudawska E., Lojalność klientów, WN PWE Warszawa 2005.

23. Sanchez A.A.L., Vijande M.L.S., Gutierrez A.A.T., Organisational learning and value creation in business markets, European Journal of Marketing, Vol 44, No 11/12 (2010).

24. Szczepańska K., Budowa wartości klienta w zarządzaniu jakością, [in:] Dobiegała- Korona B., Doligalski T. (ed.), Zarządzanie wartością klienta. Pomiar i strategie, Poltext, Warszawa 2010. 
25. Urban W., Siemieniako D., Lojalność klientów. Modele, motywacja i pomiar, PWN, Warszawa 2008.

26. Zikmund W.G., McLeod R., Gilbert V. W., Customer Relationship Management: Integrating Marketing Strategy and Information Technology, John Wiley and Sons, San Francisco 2003.

27. http://www.bain.com/bainweb/consulting_expertise/capabilities_detail.asp?capID $=102$ [accessed on 18/10/2010].

28. http://www.iclployalty.com/homePage? q=customerloyalty [accessed on 18/10/2010]. 